\title{
Potential Role of Weed Management on Growth and Productivity of Pearl Millet: A Review
}

\author{
Sindhu Lalichetti ${ }^{1}$, Sagar Lalichetti ${ }^{1 *}$, Sultan Singh ${ }^{2}$, Sagar Maitra ${ }^{1}$ and \\ Oggu Keerthipriya ${ }^{3}$
}

\begin{abstract}
${ }^{1}$ Department of Agronomy, M.S. Swaminathan School of Agriculture, Centurion University of Technology and Management, Odisha, India

${ }^{2}$ Division of Agronomy, Sher-e-Kashmir University of Agricultural Sciences and Technology, Jammu, Jammu and Kashmir, India ${ }^{3}$ Department of Agricultural Economics, M.S. Swaminathan School of Agriculture, Centurion University of Technology and Management, Odisha, India.
\end{abstract}

*Corresponding author: lalichetti.sagar@cutm.ac.in (ORCID ID: 0000-0002-1991-2865)

Paper No. 894

Received: 03-04-2021

Revised: 24-05-2021

Accepted: 12-06-2021

\begin{abstract}
Growth and productivity of pearl millet are majorly governed by climate and adopted field management practices viz. nutrient, water, weed, etc. Weeds are undesirable plants both spatially and temporally which grow in close association with the crop competing for light, moisture, spaces, and nutrients. Studies indicated that the losses due to weeds were higher compared to other crop pests, thus posing a serious threat to national food security. In this context, adopting the right and efficient method of weed control is essential to achieve the yield potential of the crop. The manual hand weeding method of weed management, although efficient, is extremely strenuous and time-consuming. Moreover, the unavailability of labor is another serious drawback of this method. Besides, cultural, mechanical, and biological methods to do not ensure complete weed removal at critical stages of the crop-weed competition, especially during bad weather conditions. Hence, chemical control is the only efficient alternative left. However, selection of crop dosage, crop stage, and variety through proper understanding of mode and mechanism of action of herbicide determine its efficiency. This review mainly focuses in providing a clear understanding of the right dose and crop stage for scheduling different herbicides solely or integrated with other methods targeting efficient weed management in pearl millet.
\end{abstract}

\section{HIGHLIGHTS}

( Herbicides application is effective to ensure higher growth, productivity and economics of pearl millet.

0 Time of herbicide application is important to manage weeds population dynamics in pearl millet.

0 Limitation in herbicidal management of grassy weeds and sedges may open a way for further research.

Keywords: Herbicide, pearl millet, atrazine, weed dynamics

Pearl millet (Pennisetum glaucum) is commonly called pearl millet. It is a monocotyledonous plant and belongs to the family Poaceae. It is the fifth most important cereal after paddy, wheat, maize, and sorghum. Pearl millet is an excellent source of carbohydrates, a large number of people in the world consumed pearl millet as a staple food to meet their food requirements. India ranks first in the area and production of pearl millet and covers an area of about 7.4 MHa, production is 9.21 Million
Tonnes, and productivity is $1231 \mathrm{Kg} / \mathrm{ha}$, respectively (GOI, 2019). However, the growth and productivity of pearl millet were influenced by many factors of which weed as a pest was widely recognized. Weeds pose a serious threat to pearl millet by reducing its ability to compete for nutrients, light,

How to cite this article: Lalichetti, S., Lalichetti, S., Singh, S., Maitra, S. and Keerthipriya, O. 2021. Potential Role of Weed Management on Growth and Productivity of Pearl Millet: A Review. IJAEB, 14(2): 169-173. Source of Support: None; Conflict of Interest: None $\infty$ 
space, and moisture. Higher persistence of weeds indicates high innate competitive ability over pearl millet; comparatively thus, the presence of weeds results in a substantial reduction of crop yield and quality of the produce (Arslan et al. 2018). In general, the most commonly observed weed flora in the pearl millet field include Cyperus rotundus, Commelina benghalensis, Echinochloa crusgalli, Leucas aspera, Digera arvensis etc. (Prabhu and Palsaniya 2016). However, weed species composition and its occurrence vary from place to place depending upon its preferable environment, micro-climatic condition, association with the host plant, soil physical and chemical properties, etc. (Petrikovszki et al. 2020).

Although hand weeding is the most effective method of weed control due to an increase in labor wages and scarcity in labor availability, this is drawing back its adoption in intensive cropping system (Chaudhary et al. 2018). Recently, the chemical control of weeds is commonly used considering its time saving, reliability, and effectiveness in controlling the weeds in pearl millet (Kantwa et al. 2020). While, because of the high spatial and high temporal variability of weed flora, the decision on selection of right herbicide, right dosage, and the right time of application was site-specific, respectively (Ustuner et al. 2020). Moreover, skillful decision-making on adopting the right herbicide and its dosage is only possible primarily through proper understanding of weed biology and its role on the growth and yield parameters of a crop (Yonli et al. 2011). This might be attributed due to the mechanism of action of herbicide selected, and dosage determines selectivity.

In the light of the above facts, it was observed that there is a dire need for a review covering the role of different herbicides on growth, yield, weed control efficiency, and economics in pearl millet for a clear understanding of herbicide adoption and rate of an application under different agroclimatic for improving the decision making ability on condition-based selection of herbicide, its dosage, and integration with other methods for efficient weed management in pearl millet.

\section{Effect of Weed Management on Plant Height}

Efficient crop weed competition and better utilization of resources through the herbicidal application were observed to increase in plant height. In a field experiment, plant height of pearl millet was significantly reported to increase with application of Atrazine@ $0.5 \mathrm{~kg}$ ai $/ \mathrm{ha}$ as pre-emergence followed by one hand weeding in kharif season and application of Pendimethalin @ $1.0 \mathrm{~kg}$ ai/ha followed by 1 hand weeding at 25 DAS in rabi season over a weedy check both in kharif and rabi, respectively under sandy clay loam soil at Gwalior, Madhya Pradesh (Tarwariya and Rajput 2019). Studies indicated that effective weed control was only possible when weeds are controlled, especially during the critical stage of weed competition. Mishra et al. (2017) reported significantly higher plant height of pearl millet with two hands weeding at 20 and 40 DAS, respectively, which is at par with pre-emergence application of Atrazine @ $750 \mathrm{~g} /$ ha followed by one hand weeding 30 DAS under sandy loam soil at Tirupati. This influence on plant height was confirmed by another experiment at Karnal, Harayana using pre-emergence application of Atrazine followed by hand weeding at 25 DAS in clay loam soil (Choudhary et al. 2018). This might be due to efficient weed control through PSII inhibition during the initial stages of weed establishment, while the hand weeding helps in a -post-emergence control of weeds owing to increase in cell division due to reduced competition of moisture in rainfed areas and for nutrients in irrigated regions. The methodologies considered by different researchers for attaining maximum plant height of pearl millet was given in the Table 1.

Table 1: Influence of herbicide application on plant height of pearl millet

\begin{tabular}{lllll}
\hline \multirow{2}{*}{ Methodologies considered } & \multirow{2}{*}{ Season } & \multicolumn{2}{c}{ Plant height (cm) } & \multirow{2}{*}{ References } \\
\cline { 3 - 5 } & & Treated & Control & \\
\hline Atrazine @ 0.5 kg ai/ha PE + 1 HW at 25 DAS & Kharif & 146.83 & 130.14 & Tarwariya and Rajput (2019) \\
$\begin{array}{l}\text { Atrazine @ 750 g a.i./ha fb hand weeding at 30 } \\
\text { DAS }\end{array}$ & Kharif & 228.8 & 162.3 & Mishra et al. (2017) \\
Pendimethalin (PE) fb 1 HW 25 DAS. & Kharif & 215.2 & 196.9 & Choudhary et al. (2018) \\
\hline
\end{tabular}




\section{Effect of Weed Management on Dry Matter}

Dry matter accumulation indicates the net quantity of photosynthates retained after utilization through respiration. This helps in the estimation of photosynthetic efficiency. Weed management through herbicides seems to play a significant role in dry matter accumulation. Since effective weed control at the right stage could minimize crop weed competition and resulted in better photosynthetic accumulation and thereby resulting increase in dry matter accumulation attributing to enhanced water and nutrient uptake from the soil. In an experiment conducted on fodder, pearl millet realized that application of either Pendimethalin or Atrazine as a pre-emergence herbicide followed by one hand weeding at 25 DAS significantly increased the dry fodder yield by $42 \%$ over weedy check while this combination was at par with weed-free plot, respectively (Choudhary et al. 2018). Similarly, in a study conducted on sandy loam soils at Annamali, Tamil Nadu it was observed that dry matter accumulation in pearl millet based cropping systems was significantly increased by two hand weedings over sole application of only pre-emergent herbicides like Pendimethalin and Alachlor @ 0.75 and $1 \mathrm{~kg}$ a.i,/ha, respectively (Ramesh and Gararira 2018). Deshveer and Deshveer (2005) observed that dry matter accumulation was maximum when both pre and post-emergent control of weeds was practiced such that sole hand weeding at 25 DAS or sole application of herbicides viz. Atrazine @ 500 g/ha, Alachlor@ 1000 g/ha, and Oxyflurofen @ $200 \mathrm{~g} /$ ha reported to accumulate significantly low crop dry matter compared with Atrazine @ 500 g/ ha, Alachlor@1000 g/ha, and Oxyflurofen @ 200 $\mathrm{g} /$ ha added up by hand weeding at 25 DAS under sandy loam at Kumher, Rajasthan.

\section{Effect of Weed Management on Pearlmillet Yield}

Higher photosynthetic efficiency and rapid translocation of photosynthates from source to sink determine the yield of a crop. Further, due to reduced competition for nutrients and moisture, efficient weed management was reported to enhance grain and stover yield upon significant influence on yield attributing characters. Consequently, enriching the source-sink relationship in pearl millet and discouraging the accumulation of dry matter in weeds minimizes competition, respectively. Studies indicated that integration of pre-emergence application of Atrazine with hand weeding at 20 DAS effectively controlled the weed population and increased the grain yield of pearl millet, significantly over other weed management practices (Mishra et al. 2017). Similarly, in an experiment conducted, two hand weedings at 20 and 40 DAS reported significantly higher grain and stover yield, which was at par with pre-emergent application of Atrazine@ $750 \mathrm{~g} /$ ha followed by one hand weeding at 20 DAS in pearl millet while an increased dose of Atrazine to $1000 \mathrm{~g} / \mathrm{ha}$ significantly reduced the grain and stover yield respectively (Kumar et al. 2019). Girase et al. (2017) realized that in the black soils of Maharashtra, application of Atrazine @ 500 $\mathrm{g} /$ ha at pre-emergence followed by the adoption of one hand weeding at 35 DAS significantly boosted the grain and stover yield of pearl millet. Similarly, the application of Atrazine @ $500 \mathrm{~g} / \mathrm{ha}$ as a preemergence herbicide followed by one hand weeding at 25 DAS in Sandy clay loam soils was significantly enhanced the grain and stover yield of pearl millet over other treatments, respectively (Tarwariya and Rajput 2019). The methodologies considered by different researchers for attaining highest grain yield of pearl millet was given in the Table 2 .

\section{Effect of Weed Management on Weed Dynamics}

Studies indicated that the application of herbicides has a significant influence on weed flora, weed density, and its dry weight in a particular location. However, the weed flora of a region is mainly dependent on the weed seed bank and prevailing

Table 2: Influence of herbicide application on grain yield of pearl millet

\begin{tabular}{lllll}
\hline \multirow{2}{*}{ Methodologies considered } & \multirow{2}{*}{ Season } & \multicolumn{2}{c}{ Grain yield (kg/ha) } & \multirow{2}{*}{ References } \\
\cline { 3 - 5 } & & Treated & Control & Kumar et al. (2019) \\
Atrazine @ 750 g/ ha (PE) + 1 HW at 20 DAS & Kharif & 1976 & 863 & Kushra et al. (2017) \\
Atrazine @ 750 g/ha (PE) + HW at 30 DAS & Kharif & 2936 & 1595 & Mishra \\
Atrazine @ 0.5 kg/ha (PE) + HW at 35 DAS & Kharif & 3100 & 1910 & Girase et al. (2017) \\
\hline
\end{tabular}


micro-climatic conditions. Prabhu and Palsaniya (2016) realized that in sandy clay loam soil with acidic $\mathrm{pH}$, broadleaf weeds like Commelina benghalensis, Echinocloa crusgalli and Cyperus rotandus dominated the experimental field. However, maximum weed density and dry weight were recorded in weedy check, and the lowest weed densities were recorded with the pre-emergence application of Oxadiargyl @ 90 g/ha followed by 2,4-D ethyl ester @ $1 \mathrm{~kg} / \mathrm{ha}$. Consequently, this treatment further recorded the highest weed control efficiency and weed index, respectively. Similarly, in a field experiment, it was observed that carpetweed, Cyperus rotandus, Echinocloa colonum, Euphorbia spp. and Cynodon dactylon found to predominate in sandy loam textured soil with alkaline $\mathrm{pH}$ and recorded significantly lower weed density when herbicides were followed up by hand weeding at 25 DAS compared to their sole herbicide application. Among these herbicides Oxyflurofen application @200, g/ha performed superior, recording 94.1\% less weed dry matter in comparison with other treatments (Deahveer and Deshveer 2005). In a research conducted at pearl millet research station at Junagarh, Atrazine application followed by one hand weeding was observed to perform significantly superior over weedy check-in controlling the weed flora in the experimental site. Broad leaf weeds were efficiently controlled by post-emergence application Atrazine @ $400 \mathrm{~g} / \mathrm{ha}$ along with one hand weeding at 35 DAS. However, pre-emergence application Atrazine @ $500 \mathrm{~g} /$ ha followed by one hand weeding at 35 DAS reported to control grassy weeds only at 30 DAS but found to be inefficient at harvesting (Bhuva and Detroja 2018). Similarly, pre-emergence application of Pretilachlor @ $450 \mathrm{~g} / \mathrm{ha}$ recorded significantly lower weed count both at 30 and 60 DAS than a pre-emergence application of Atrazine @ $750 \mathrm{~g} / \mathrm{ha}$ in comparison, which is in the tune of 8.87 and 10.33, respectively, thus registered higher weed control efficiency compared to other herbicidal treatments in comparison (Ramesh et al. 2019).

\section{Effect of Weed Management on Relative Economics}

Herbicidal utilization in weed management is gaining wide recognition as a cost-effective and economical practice. This might have attributed to weed control treatment that recorded superior grain and stover yield, comparatively. Studies indicated that pre-emergence application of Atrazine @ $750 \mathrm{~g} / \mathrm{ha}$ in addition to hand weeding at $20 \mathrm{DAS}$ significantly recorded the highest net returns and B:C ratio to the tune of $₹ 23332$ and 1.91 over control, respectively (Kumar et al. 2019). However, an experiment conducted at Bapatla under sandy textured soil with an alkaline $\mathrm{pH}$ found to record significantly superior grain and stalk yield with post-emergence application of metsulfuron along with chlorimuron ethyl @ $2 \mathrm{~g} /$ a.i./ ha each at 20 DAS and subsequently attributed to record higher net returns and $\mathrm{B}: \mathrm{C}$ ratio over other treatments in comparison (Lakshmi Thanmai et al. 2018).

\section{CONCLUSION}

According to this review, it can be concluded that herbicides play a key role in weed management of pearl millet, ensuring food and nutritional security. Application of pre-emergence herbicide with longer persistence in soil followed by hand weeding was observed to be a right alternative to manual weeding. Although recommendation and selection of herbicide were site specific and mainly depended on microclimate and soil in which pearl millet is cultivated. This review also provided an insight on understanding the right time of application of herbicide considering its persistence in the soil and weed flora in that region, subsequently targeting selective crop simulation facilitating the pearl millet to compete efficiently with weed for light, moisture, carbon dioxide, and nutrient, respectively. Further, this helped in identifying considerable lacunae such as herbicidal inefficiency in controlling grassy weeds and sedges compared to broadleaf weeds with present-day available technology in pearl millet. It is high time for the researchers to look into these lacunae and strive to put up necessary efforts aiming to fulfill this gap.

\section{REFERENCES}

GOI 2019. Agricultural Statistics at a Glance. Department of Agriculture Cooperation and Farmers Welfare. Directorate of Economics and Statistics. https://eands. dacnet.nic.in/PDF/At\%20a\%20Glance\%202019\%20Eng. pdf [Accessed Online: Date $1^{\text {st }}$ May 2021, Time 17:33]

Arslan, N., Zulfiqar, U., Ishfaq, M., Ahmad, M., Anwar, M.N., Ullah, A. and Anjum, M.Z. 2018. Weed control practices and varying sowing dates effects on seed production of Pearl Millet (Pennisetum americanum L.) under semi-arid environment. Am. J. Plant Sci., 9(9): 1974-1986. 
Bhuva, H.M. and Detroja, A.C. 2018. Pre-and post-emergence application of Atrazine in integration with hand weeding for weed management in pearl millet. Indian J. Weed Sci., 50(3): 273-277.

Choudhary, S., Chopra, N.K. and Chopra, N.K. 2018. Effect of nitrogen application and weed management schedules on growth, yields and economics of forage pearl millet (Pennisetum glaucum L.). Int. J. Chem. Stud., 6(3): 3530-3534.

Chaudhary, C., Dahiya, S., Rani, S. and Pandey, S. 2018. Review and outlook of weed management in Pearl millet. Int. J. Chem. Stud., 6(2): 2346-2350.

Deshveer, C.L. and Deshveer, L.S. 2005. Weed management in pearl millet (Pennisetum glaucum) with Special Reference to Trianthema portulacastrum. Indian J. Weed Sci., 37(3-4): 212-215.

Girase, P.P., Suryawanshi, R.T., Pawar, P.P. and Wadile, S.C. 2017. Integrated weed management in pearl millet. Indian J. Weed Sci., 49(1): 41-43.

Kumar, Y.S.R., Kumar, R., Baba, Y.A. and Samruthi, M. 2019. Effect of integrated weed management on yield, yield attributes and economics of pearl millet [Pennisetum glaucum (L.) R. Br. Emend Stuntz]. Int. J. Curr. Microbiol. App. Sci., 8(10): 2629-2633.

Kantwa, S.R., Govindasamy, P., Palsaniya, D.R. and Kumar, S. 2020. Herbicide application improved weed control and yield in Bajra Napier hybrid. Indian J. Agric. Sci., 90(7): 1297-1301.

Lakshmi Thanmai, P., Srinivasulu, K., Prasad, P.V.N. and Ravindra Babu, P. 2018. Evaluation of post-emergence herbicides in pearl millet (Pennisetum typhoides). Int. J. Chem. Stud., 6(3): 631-633.
Mishra, P.S., Ramu, R.Y., Subramanyam, D. and Umamahesh, V. 2017. Impact of integrated weed management practices on weed dynamics, growth and yield of pearl millet [Pennisetum Glaucum L. Br. Emend. Stuntz.]. Int. J. Agric. Sci., 9(3): 3677-3679.

Petrikovszki, R., Zalai, M., Tothne Bogdanyi, F. and Toth, F. 2020. The effect of organic mulching and irrigation on the weed species composition and the soil weed seed bank of tomato. Plants, 9(1): 66.

Prabhu, G. and Palsaniya, D.R. 2016. Screening of herbicides for effective weed control in Bajra Napier hybrid. Range Manag. Agrofor., 37(1): 73-78.

Ramesh, N. and Gararira, P.C. 2018. Integration of herbicides with manual hand weeding for controlling the weeds in pearlmillet based on intercropping system (Pennisetum glaucum). Int. J. Agri. Statisti. Sci., 10(18): 7255-7258.

Ramesh, N., Kalamani, M., Baradhan, G., Kumar, S.M. and Ramesh, S. 2019. Influence of weed management practices on nutrient uptake and productivity of hybrid Pearl Millet under different herbicides application. Plant Arch., 19(2): 2893-2898.

Tarwariya, M.K. and Rajput, R.K. 2019. Effect of weed and tillage management practices on growth and yield of Pearl Millet (Pennisetum glaucum)-Mustard (Brassica juncea) cropping system. Int. J. Pure App. Bio. Sci., 7(3): 606-612.

Ustuner, T., Sakran, A. and Almhemed, K. 2020. Effect of herbicides on living organisms in the ecosystem and available alternative control methods. IJSRP., 10(8): 633.

Yonli, D., Traore, H., Van Mourik, T.A., Hess, D.E., Sereme, P. and Sankara, P. 2011. Integrated control of Striga hermonthica (Del.) Benth. in Burkina Faso through host plant resistance, biocontrol and fertilizers. Int. J. Bio Chem. Sci., 5(5): 1860-1870. 
